\title{
Hematologi Anak Domba Garut Prasapih yang Diberi Milk Replacer Terformulasi Minyak Ikan Lemuru dan Minyak Canola
}

\author{
Fajar Nurani*, Asep Sudarman, Lilis Khotijah \\ Departemen Ilmu Nutrisi dan Teknologi Pakan, Institut Pertanian Bogor \\ Kampus IPB Dramaga, Bogor, Indonesia \\ *Email korespondensi: fajar.nurani10@gmail.com
}

(Diterima: 07-07-2019; disetujui 15-08 -2019)

\begin{abstract}
ABSTRAK
Penelitian ini bertujuan untuk mengevaluasi pemberian milk replacer yang mengandung minyak ikan lemuru dan canola terhadap hematologi anak domba Garut prasapih. Rancangan percobaan yang digunakan adalah rancangan acak lengkap (RAL) dengan tiga perlakuan dan enam ulangan. Anak domba prasapih dengan bobot badan berkisar 2,3 $\pm 0,42 \mathrm{~kg}$ dibagi secara acak ke dalam kandang individu dan mendapatkan perlakuan $\mathrm{P} 0=$ susu domba yang berasal dari susu induk domba, $\mathrm{P} 1=$ milk replacer terformulasi susu sapi + kuning telur + minyak ikan + premix, dan $\mathrm{P} 2=$ milk replacer terformulasi susu sapi + kuning telur + minyak ikan + minyak canola + premix. Parameter yang diamati adalah hematologi yang terdiri atas kadar hemoglobin, hematokrit, eritrosit dan leukosit. Data hasil penelitian dianalisis sidik ragam. Hasil penelitian menunjukan bahwa milk replacer yang diformulasi minyak ikan lemuru, dan atau minyak canola tidak berbeda terhadap hematologi anak domba prasapih dibandingkan dengan kontrol. Kesimpulan penelitian ini adalah minyak ikan lemuru dan atau minyak canola sebagai sumber lemak dapat digunakan dalam milk replacer domba tanpa adanya pengaruh negatif terhadap gambaran hematologi anak domba.
\end{abstract}

Kata kunci: anak domba garut prasapih, hematologi, minyak canola, minyak ikan lemuru, milk replacer

\section{ABSTRACT}

The study aimed to evaluate the effect a milk replacer containing lemuru fish oil and canola oil on hematology of Garut twin lambs before weaning. The study used a completely randomized design (CRD) with three treatments and six replicates. The pre-weaning lamb with average $2,3 \pm 0,42 \mathrm{~kg}$ of body weight, which were randomly divided into individual pen with $\mathrm{P} 0=$ milk sourced from mother milk, $\mathrm{P} 1=$ milk sourced from milk replacer, cow milk + lemuru fish oil + yolk + premix, $\mathrm{P} 2=$ milk sourced from milk replacer, cow milk + lemuru fish oil+canola oil+yolk+ premix. Measurements were taken on levels of hemoglobin, hematocrit, erythrocyte, and leukocyte. Data were analyzed using analysis of variance. The results show that the milk replacer containing lemuru fish oil and or canola oil was similar to blood hematology of preweaning lambs compared to control. It was concluded that lemuru fish oil and canola oil can use in milk replacer without any negative effect on the blood hematology.

Keywords: canola oil, hematolog, lemuru fish oil, milk replacer, pre-wearing garut lam

\section{PENDAHULUAN}

Domba Garut merupakan salah satu sumber daya genetik ternak (SDGT) khas Jawa Barat dan memiliki peranan yang penting dalam memenuhi kebutuhan produk hewani nasional meskipun permintaan daging domba tidak setinggi daging sapi. Domba Garut memiliki sifat beranak banyak dalam satu kali kelahiran (prolifik). Keuntungan dari sifat prolifik, yaitu mampu meningkatkan populasi domba dengan waktu yang lebih singkat dan profit peternak domba dapat meningkat (karena harga jual domba Garut mahal) apabila sifat prolifik dimanfaatkan dengan baik. Sifat prolifik memiliki kekurangan diantaranya tingginya mortalitas anak domba sebelum disapih, kecilnya bobot lahir dan bobot sapih serta rendahnya laju pertumbuhan anak (Inounu, 2011). 
Tingkat mortalitas anak domba Garut lebih tinggi pada anak domba yang dilahirkan kembar lebih dari $2(88.9 \%)$ dibandingkan dengan anak domba lahir kembar $2(30 \%)$ atau tunggal (10\%) (Adiati \& Subandriyo, 2007). Tingginya tingkat mortalitas anak domba diduga karena produksi susu induk yang terbatas untuk menyuplai susu bagi anak yang dilahirkan, induk tidak bisa menyusui atau terjadi persaingan antar anak untuk mendapatkan susu. Banyaknya anak domba yang dilahirkan memerlukan ekstra perhatian dan waktu peternak untuk mengelolanya, sedangkan yang bisa bertahan hidup sampai lepas sapih biasanya hanya 1 ekor. Hal tersebut mengakibatkan kelahiran anak domba kembar kurang diinginkan oleh peternak.

Susu merupakan sumber pakan utama anak domba sehingga ketersediaan dan produksi susu induk sangat penting dalam memenuhi kebutuhan nutrien yang dapat menentukan daya hidup dan pertumbuhan anak prasapih. Perbedaan produksi susu domba Garut antara induk dengan kelahiran anak tunggal dan kembar 2 yaitu $10 \%$ dan terjadi perbedaan yang lebih tinggi pada induk dengan kelahiran kembar 4 (Tiesnamurti, 2002). Salah satu solusi yang dapat dilakukan untuk mencukupi kekurangan susu induk yaitu dengan pemberian milk replacer.

Milk replacer atau susu pengganti yaitu campuran berbagai jenis bahan pakan yang dapat digunakan sebagai pengganti susu induk, diformulasikan dari susu atau berbagai produk sampingan industri susu dengan penambahan beberapa bahan lain yang disesuaikan dengan komposisi susu induknya (Khan et al., 2012). Pemberian milk replacer yang disuplementasi linseed pada anak domba Malpura selama periode prasapih dapat menghasilkan pertambahan bobot badan harian (187 g/hari) lebih besar dari ternak kontrol, (161 g/hari) (Bhatt et al., 2018). Penggunaan milk replacer di Indonesia masih belum umum digunakan, hal ini disebabkan karena peternakan domba di Indonesia kebanyakannya masih berupa peternakan rakyat dengan skala kecil dan milk replacer komersial relatif mahal.

Pembuatan milk replacer sebaiknya menggunakan bahan-bahan yang mudah diperoleh dan mempunyai harga yang relatif murah, salah satunya susu sapi. Produksi susu sapi di Indonesia lebih banyak dibandingkan dengan produksi susu ternak lainnya, sehingga digunakan sebagai bahan dasar dalam pembuatan milk replace. Susu sapi mengandung protein $(3,50 \%)$ dan lemak $(3,60 \%)$ lebih rendah dibandingkan dengan protein $(5,590 \%)$ dan lemak $(6,820 \%)$ susu domba (Suprijati, 2014), sehingga penambahan sumber protein dan lemak diperlukan dalam pembuatan milk replacer agar komposisi susu sapi mendekati komposisi susu domba. Kandungan protein dan lemak susu sapi dapat ditingkatkan dengan penambahan kuning telur dan minyak hewani atau nabati.

Harun (2012) melaporkan bahwa penambahan minyak ikan sebagai sumber lemak dalam milk replacer anak domba lokal dapat menghasilkan anak domba yang sehat dengan tidak ada kematian. Selain sebagai sumber lemak, minyak ikan kaya omega-3. Beberapa kajian menyatakan bahwa penambahan omega-3 dapat memperbaiki daya tahan tubuh anak (Pickard et al., 2008; Capper et al., 2006). Penambahan minyak nabati, seperti minyak canola perlu ditambahkan dalam pembuatan milk replacer, selain sebagai sumber lemak, minyak canola dapat dijadikan sebagai sumber omega-6 yang dapat mendukung dari fungsi omega-3 yang terkandung dalam minyak ikan. Asam lemak omega-3 dan omega-6 adalah asam lemak tak jenuh yang termasuk kedalam golongan Poly Unsaturated Fatty Acid (PUFA) dan juga termasuk dalam kelompok asam lemak esensial. Asam lemak omega-3 dan omega-6 tidak dapat disintesis dalam tubuh sehingga perlu dipenuhi dalam pakan.

Pemberian milk replacer dengan penambahan minyak ikan lemuru dan minyak canola sebagai sumber lemak yang berbeda memungkinkan terjadinya perubahan fisiologis ternak. Oleh karena itu, perlu diteliti perubahan fisiologis ternak yang meliputi jumlah hemoglobin, hematokrit, leukosit dan eritrosit sebagai akibat dari pemberian milk replacer. Semua unsur tersebut memiliki peranan penting dalam proses metabolisme tubuh ternak, jika terjadi perubahan unsur tersebut dalam tubuh maka akan terjadi perubahan proses metabolisme yang akan berdampak pada performa ternak. Tujuan dari penelitian ini adalah untuk mengevaluasi pemberian milk replacer yang diformulasi dengan minyak ikan lemuru dan minyak canola terhadap hematologi anak domba garut prasapih. 


\section{MATERI DAN METODE}

\section{Metode Penelitian}

Penelitian dilaksanakan di UPTD Balai Pengembangan Perbibitan Ternak Domba dan Kambing Margawati Kabupaten Garut, Dinas Ketahanan Pangan dan Peternakan Jawa Barat. Delapan belas ekor anak domba garut kelahiran kembar 2 (jantan-betina, berasal dari 9 ekor induk berbeda) dialokasikan secara acak ke dalam 3 macam perlakuan dan ditempatkan ke dalam kandang individu. Domba tersebut berumur 1 minggu dengan bobot badan $2,3 \pm 0,42 \mathrm{~kg}$. Perlakuan kontrol $\left(\mathrm{P}_{0}\right)$ yaitu susu domba yang berasal dari susu induk domba yang dikonsumsi oleh anak yang dikandangkan bersama dengan induknya, sementara perlakuan satu $\left(\mathrm{P}_{1}\right)$ yaitu milk replacer terformulasi (minyak ikan) yang diberikan pada anak domba yang dipisahkan dari induknya, dan perlakuan dua $\left(\mathrm{P}_{2}\right)$ yaitu milk replacer terformulasi (minyak ikan + minyak canola) yang diberikan pada anak domba yang dipisahkan dari induknya.

Milk replacer (Tabel 1) diberikan 4 kali sehari dengan menggunakan botol susu plastik (kapasitas $250 \mathrm{ml}$ ). Masing-masing anak domba diberi milk replacer ad libitum. Pemberian milk replacer dilakukan sampai anak domba berumur 2 bulan. Pengambilan sampel darah dilakukan pada pagi hari sebelum ternak diberi pakan. Sampel darah diambil pada hari terakhir pemberian milk replacer. Darah diambil pada bagian vena jugularis atau daerah sekitar leher pada anak domba, dengan cara memasukan syringe pada bagian tersebut (membentuk sudut $30^{\circ}$ dari pangkal leher) menggunakan syringe 3 $\mathrm{mL}$, lalu darah yang sudah terambil dimasukkan ke dalam tabung yang mengandung antikoagulan EDTA. Botol tersebut dimasukan kedalam termos yang berisi es untuk selanjutnya dibawa ke laboratorium untuk dianalisis. Sampel darah dianalisis menggunkan hematologi analyzer di Laboratorium Sentral Universitas Padjadjaran. Nilai-nilai hematologi yang diamati meliputi jumlah hemoglobin, hematokrit, eritrosit, dan leukosit. Data yang diperoleh dianalisis menggunakan sidik ragam pada taraf nyata $5 \%$.

\section{HASIL DAN PEMBAHASAN}

Hasil penelitian menunjukan bahwa penggunaan minyak ikan lemuru dan minyak canola sebagai sumber lemak yang berbeda pada milk replacer tidak memberikan pengaruh nyata $(\mathrm{P}>0,05)$ terhadap kadar hemoglobin, persentase hematokrit, jumlah eritrosit dan jumlah leukosit (Tabel 2).

Tabel 1. Kandungan nutrien susu domba dan milk replacer

\begin{tabular}{lccc}
\hline Kandungan nutrien* & $\mathrm{P}_{0}$ & $\mathrm{P}_{1}$ & $\mathrm{P}_{2}$ \\
\hline Bahan kering (\%) & 16,54 & 16,34 & 16,52 \\
Protein kasar (\%) & 20,92 & 20,87 & 20,70 \\
Lemak kasar (\%) & 34,49 & 35,56 & 35,84 \\
Serat kasar (\%) & 0 & 0 & 0 \\
Kalsium & 1,06 & 1,02 & 1,02 \\
Fosfor & 0,85 & 0,81 & 0,81 \\
\hline
\end{tabular}

$\mathrm{P}_{0}$ : susu domba induk; $\mathrm{P}_{1}$ : Milk replacer yang diformulasikan $3 \%$ minyak ikan; $\mathrm{P}_{2}$ : Milk replacer yang diformulasikan $1 \%$ minyak ikan $+2 \%$ minyak canola; $*$ hasil analisis Laboratorium Sentral Universitas Padjadjaran (2019)

Tabel 2. Hematologi anak domba Garut prasapih yang diberi milk replacer

\begin{tabular}{lrrrr}
\hline Parameter & \multicolumn{1}{c}{$\mathrm{P}_{0}$} & \multicolumn{1}{c}{$\mathrm{P}_{1}$} & \multicolumn{1}{c}{$\mathrm{P}_{2}$} & \multicolumn{1}{c}{ Normal } \\
\hline Hemoglobin $(\mathrm{g} / \mathrm{dL})$ & $12,70 \pm 0,80$ & $10,88 \pm 2,52$ & $10,80 \pm 1,79$ & $9-15^{*}$ \\
Hematokrit $(\%)$ & $29.00 \pm 1,06$ & $28,33 \pm 0,80$ & $27,5 \pm 0,62$ & $27-45^{*}$ \\
Leukosit $\left(10^{3} / \mathrm{mm}^{3}\right)$ & $9,25 \pm 1,58$ & $10,10 \pm 3,05$ & $11,82 \pm 2,90$ & $9-14^{*}$ \\
Eritrosit $\left(10^{6} / \mathrm{mm}^{3}\right)$ & $4,63 \pm 1,02$ & $4,43 \pm 1,42$ & $4,29 \pm 0,58$ & $4-12^{* *}$ \\
\hline
\end{tabular}

$\mathrm{P}_{0}$ : susu domba induk; $\mathrm{P}_{1}$ : Milk replacer yang diformulasikan $3 \%$ minyak ikan; $\mathrm{P}_{2}$ : Milk replacer yang diformulasikan $1 \%$ minyak ikan $+2 \%$ minyak canola; *: Nilai normal berdasarkan Weiss \& Wardrop (2010); **: Smith \& Mangkoewidjojo (1988) 
Nilai hemoglobin hasil penelitian pada anak domba yang diberi milk replacer yaitu 10,88 dan $10,8 \mathrm{~g} / \mathrm{dL}$ dan lebih rendah dari nilai hemoglobin anak domba yang dipelihara bersama induknya yaitu $12,7 \mathrm{~g} / \mathrm{dL}$. Meskipun demikian, hasil tersebut menunjukan nilai hemoglobin masih dalam kisaran normal (9-15 $\mathrm{g} / \mathrm{dL}$ ) namun cenderung pada ambang batas rendah. Hal tersebut diduga karena kurangnya prekursor seperti zat besi dan globin yang membantu proses pembentukan eritrosit yang juga akan menyebabkan penurunan hemoglobin. Selain itu, diduga karena jumlah protein pakan yang diberikan masih kurang sehingga akan mempengaruhi produksi eritrosit. Protein merupakan salah satu komponen penyusun hemoglobin yang dapat membantu dalam pembentukan eritrosit (Leovansa, 2013). Apabila konsumsi protein rendah maka asam amino seperti glisina juga rendah dan akan menghambat pembentukan hemoglobin dan eritrosit. Hemoglobin yang dominan tersusun dari senyawa protein (globin) berasal dari protein asupan pakan dan disintesa dalam tubuh domba. Rendahnya jumlah hemoglobin berbanding lurus dengan jumlah eritrosit. Hal ini sesuai dengan pendapat Reeca (2006), hemoglobin terdapat dalam eritrosit dan mengisi sepertiga dari komponen eritrosit setelah air dan sitoplasma, jadi ketika jumlah hemoglobin rendah maka jumlah eritrosit juga rendah.

Pengukuran jumlah eritrosit menjadi bagian penting dalam penelitian, karena eritrosit merupakan sel darah yang memiliki fungsi untuk mengikat dan mengedarkan oksigen ke seluruh jaringan tubuh (Ganong, 2003). Hasil yang diperoleh dari penelitian menunjukan bahwa jumlah eritrosit penelitian berada dalam kisaran normal menurut Smith \& Mangkoewidjojo (1988), yaitu 4,29-4,63 $10^{6} / \mathrm{mm}^{3}$, namun cenderung pada batas rendah. Penambahan minyak ikan lemuru dan minyak canola pada milk replacer tidak memberikan pengaruh nyata terhadap eritrosit diduga juga akibat tidak berbeda nyata protein ataupun lemak yang dikonsumsi oleh domba penelitian. Protein digunakan sebagai komponen dalam pembuatan eritrosit, apabila protein yang dikonsumsi rendah secara langsung mempengaruhi jumlah eritrosit. Eritrosit secara tidak langsung membutuhkan asam lemak esensial dalam memperbaiki selnya. Menurut Fritsche et al., (1992), asam lemak esensial diduga dapat membantu pembentukan prostaglandin untuk memperbaiki sel darah merah. Adapun faktor lain yang dapat mempengaruhi jumlah eritrosit yaitu kandungan vitamin, serta beberapa mineral seperti $\mathrm{Cu}, \mathrm{Fe}$, $\mathrm{Mn}$, dan Co, jenis kelamin, umur, hormon, dan lingkungan penelitian.

Hematokrit adalah persentase sel darah merah dalam $100 \mathrm{~mL}$ darah. Nilai hematokrit pada ternak normal sebanding dengan jumlah eritrosit dan kadar hemoglobin. Nilai hematokrit penelitian pada anak domba yang diberi milk replacer yang mengandung minyak ikan dan minyak canola yaitu 28.33 dan $27.5 \%$ sedangkan untuk anak domba yang dipelihara bersama induknya adalah $29 \%$. Nilai hematokrit penelitian berada dalam kisaran normal menurut Weiss dan Wardrop (2010) yaitu 27$45 \%$. Berdasarkan hasil analisis statistik menunjukan bahwa tiap perlakuan tidak berbeda nyata terhadap kadar hematokrit. Hal tersebut dikarenakan jumlah hemoglobin dan eritrosit pada penelitian ini tidak berbeda nyata. Nilai hematokrit pada ternak normal sebanding dengan jumlah eritrosit dan kadar hemoglobin. Nilai hematokrit dipengaruhi oleh beberapa faktor diantanya, lokasi penelitian, jenis ternak, dan jenis kelamin. Selain itu, redahnya nilai hematokrit diduga karena konsumsi air yang minum yang rendah. Hematokrit merupakan persentase sel darah merah di dalam darah, dimana kandungan air dalam darah juga berpengaruh terhadap kadar hematokrit. Nilai hematokrit menggambarkan secara langsung viskositas darah dan secara tidak langsung jumlah sel darah merah (Frandson, 1992). Secara fisiologis, nilai hematokrit pada anak domba akan lebih rendah dengan kondisi ketika dewasa, karena pada anak domba yang baru lahir sel darah hanya di produksi di sumsum tulang sedangkan pada domba dewasa diproduksi di sumsum tulang membranosa, seperti vertebra, stenum, rusuk, dan ilium (Guyton \& Hall, 1997). Hematokrit yang rendah dapat mengidikasikan beberapa kelainan antara lain anemia, kerusakan sumsum tulang, kerusakan sel darah merah, dan malnutrisi.

Leukosit merupakan komponen darah yang berperan dalam mempertahankan sistem imun tubuh yang bertugas memusnahkan benda-benda asing yang berbahaya bagi tubuh. 
Jumlah leukosit dapat dijadikan tolok ukur kondisi kesehatan ternak. Hasil penelitian menunjukan bahwa jumlah leukosit berkisar antara 9,25-11,82 $10^{3} / \mathrm{mm}^{3}$. Jumlah leukosit penelitian masih berada pada kisaran normal (9$1410^{3} / \mathrm{mm}^{3}$ ) berdasarkan Weiss \& Wardrop (2010). Di dalam aliran darah kebanyakan selsel darah putih bersifat non fungsional dan hanya diangkat kejaringan ketika dibutuhkan saja. Keadaan normal pada leukosit dapat diartikan tidak terjadinya gangguan non spesifik terhadap tubuh domba. Walaupun tidak menunjukan perbedaan nyata $(\mathrm{P}>0,05)$ namun jumlah leukosit pada anak domba yang diberi milk replacer terformulasi minyak ikan lemuru dan milk replacer terformulasi minyak ikan lemuru + minyak canola (secara berturut-turut yaitu, 10,10 dan $11,8210^{3} / \mathrm{mm}^{3}$ ) lebih tinggi dibandingkan dengan anak domba yang mengkonsumsi susu induknya $\left(9,2510^{3} / \mathrm{mm}^{3}\right)$. Tingginya jumlah leukosit pada anak domba yang diberi milk replacer diduga ada kaitannya dengan penambahan minyak ikan lemuru dan minyak canola. Selain sebagai sumber lemak hewani, minyak ikan lemuru mengandung juga omega-3 yang diduga berperan dalam produksi leukotrinea (LT4) yang merupakan komponen sel darah putih dan mediator dalam sistem pembentukan kekebalan tubuh, sedangkan minyak canola mengandung omega-6 yang dapat mendukung fungsi dari omega-3. Akan tetapi, mekanisme asam lemak omega-3 terhadap daya tahan tubuh anak masih belum dapat ditentukan secara pasti (Sinclair, 1993).

\section{KESIMPULAN}

Penambahan minyak ikan lemuru dan minyak canola pada milk replacer sebagai sumber lemak tidak memberikan pengaruh negatif terhadap gambaran hematologi anak domba Garut selama prasapih.

\section{UCAPAN TERIMAKASIH}

Terima kasih disampaikan pada UPTD Balai Pengembangan dan Perbibitan Ternak Domba dan Kambing Margawati Kabupaten Garut, Dinas Ketahanan Pangan dan Peternakan Provinsi Jawa Barat yang telah mendukung dan memberikan fasilitas penelitian. Lembaga Pengelola Dana Pendidikan (LPDP) Kementrian Keuangan yang telah memberikan beasiswa dana penelitian.

\section{DAFTAR PUSTAKA}

Adiati, U. \& Subandriyo. 2007. Produktivitas domba Garut pada stasiun percobaan Cilebut Bogor. Prosiding Seminar Nasional Peternakan dan Veteriner, Pusat Penelitian dan Pengembangan Peternakan. Bogor. Hlm.436-440.

Astuti, D.A., D.R Ekastuti, Y. Sugiarti, \& Marwah. 2008. Profil darah dan nilai hematologi domba lokal yang dipelihara di hutan pendidikan gunung walat sukabumi. Agripet: 2(8):1-8.

Bhatt, R.S., A. Sahoo, \& Y. Gadekar .2018. Production performance of lambs on milk replacer during pre-weaning followed by post-weaning linseed and calcium soap supplementation. Anim Feed Sci. 240:145-156.

Capper, J.L., Robert, G., Wilkinson, M. Alexander, Mackenzie, L.A. Sinclair 2006. Polyunsaturated fatty acid supplementation during pregnancy alters neonatal behaviour in sheep, nutrient physiology, metabolism and nutrientnutrient interactions. J. Nutr. 126:397403.

Frandson, R.D. 1992. Anatomi dan Fisiologi Ternak. Edisi ke-3. UGM Press. Yogyakarta.

Fritsche, K.L., N.A. Cassity, \& S.C. Huang. 1992. Dietary (n-3) fatty acid and vitamin $E$ interactions in rats: Effect on vitamin $E$ status, immune cell prostaglandin E production and primary antibody response. J Nutr. 122:1009-1018.

Ganong, W.F. 2003. Buku Ajar Fisiologi Kedokteran. Edisi ke-20. Widjajakusumah D., D. Irawati, M. Siagian, D. Moeloek, \& B.U. Pendit (penerjemah). ECG. Jakarta.

Guyton AC, \& E.J. Hall. 1997. Buku Ajar Fisiologi Kedokteran. Edisi ke-9. Irawati, (penerjemah). EGC. Jakarta.

Harun, F. 2012. Formulasi dan evaluasi milk replacer terhadap performa anak domba lokal kembar dua pra dan pascasapih. Institut Pertanian Bogor. Bogor.

Inounu, I. 2011. Pembentukan domba komposit melalui teknologi persilangan dalam upaya 
peningktan mutu genetik domba lokal. J Pengembangan Ino Pert. 4(3):218-230.

Khan, M.A., G. Sajj, A.Bahkt, D. Khan, M.K. Iqbal, F. Pervez, \& H. Pakistan. 2012. Effect of milk replacer on performance parameters of different bovine breeds. J Nutr. 11(12):1190 -1193.

Leovansa, W.A. 2013. Pemberian cassabio dalam konsentrat terhadap status fisiologi, profil hematologi dan urea darah domba ekor gemuk. Institut Pertanian Bogor. Bogor.

Pickard, R.M., A.R. Beard, C.J. Seal, \& S.A. Edwards. 2008. Neonatal lamb vigour is improved by feeding docohexanoic acid in the form of algal biomass during late gestation. Anim. Prod. Sci 2:1186-1192.
Reece, W.O. 2006. Functional anatomy and physiology of domestic animals. 3rd Edition. Blackwell Publishing, USA.

Smith, J.B., \& S. Mangkoewidjojo. 1988. Pemeliharaan, Pembiakan dan Penggunaan Hewan Percobaan di Daerah Tropis. UI Press. Jakarta.

Suprijati. 2014. Pemanfaatan susu pengganti untuk anak domba dan kambing periode prasapih. Wartazoa 24(3):139-150.

Tiesnamurti, B., I. Inounu, \& Subandriyo. 2002. Kapasitas produksi susu domba peridi: I. Pertumbuhan anak prasapih. JITV 7:227236.

Weiss, D.J., \& K.J. Wardrop. 2010. Schalm's Veterinary Hematology. Blackwell Publishing, USA. 